\title{
ヘビ型ロボットの接地部反カを考慮した跳躍制御
}

\author{
田 中 基 康*1 星 野 恵 一*2 福 島 宏 明*3 松 野 文 俊*3
}

\section{Jumping Control of Snake Robots with Considering Reaction Force at Grounding Part}

\author{
Motoyasu Tanaka*1, Keiichi Hoshino*2, Hiroaki Fukushima*3 and Fumitoshi Matsuno ${ }^{* 3}$
}

\begin{abstract}
This paper proposes a controller for the jumping motion of the 3-dimensional snake robot which has passive wheels and active universal joints. We assume that the snake robot jumps from the initial posture which some forward links are lifted up. First, we derive a dynamic model of the robot with considering the contact force and the frictional force between the robot and the flat surface. Next, we propose a controller which the snake robot jumps without slipping and the evaluation function to select the initial posture with consideration of the constraint force ellipse. Simulation and experimental results show the effectiveness of the proposed controller and the evaluation function.
\end{abstract}

Key Words: Snake Robot, Redundancy, Jumping Motion Control, Constraint Force Ellipse

\section{1.はじめに}

ヘビは手足のない細長い体幹という単純な形態であるにもか かわらず, 様々な動作や推進が可能である $[1]$. これらの特徵を 模做したへビ型ロボットの機構や推進，およびその制御に関し て多くの研究が行われている. 先行研究ではうねり推進 [2], サ イナスリフティング滑走 [3], 巻きつき [4] などのへビの一般的 な運動について研究がされている。一般的にへビは跳躍力がな いとされているが, マムシやジャンピングピットバイパーなど の種は跳躍能力が高いことが知られている。へビ型ロボットの 跳躍運動を実現することができれば，新たな運動能力を付加し， ヘビ型ロボットの運動性能の向上が期待できる。 そこで, 本研 究ではへビ型ロボットの跳躍制御について考える。ここで, 跳 躍とは, 接地したロボットが離床し, その離床中にロボットが目 標の方向へ移動し再度着床することと定義する。 また, 本研究 では接地したロボットが離床するまでの運動を跳躍運動と呼ぶ.

本研究では受動車輪（以下，単に車輪とする）によって生物 のへビの体幹に存在する摩擦の異方性をモデル化した車輪拘束 ヘビ型ロボット [1]（以下, 単にヘビ型ロボットとする）を研究 対象として扱う。このへビ型ロボットのように能動回転関節を 有し冗長性をもつ跳躍ロボットとして動物の脚機構を規範とし たロボットやヒューマノイドなどが挙げられる. 美多らはカン

\footnotetext{
原稿受付 2013 年 2 月 6 日

*1電気通信大学

*2 株式会社リコー

*3 京都大学

${ }^{* 1}$ The University of Electro-Communications

${ }^{* 2}$ Ricoh Company Ltd

${ }^{* 3}$ Kyoto University
}

ガルーの跳躍運動を解析し，それに基づいた走行を実現するよ うに一脚ロボットの跳躍走行制御を行った [5]. また，ヒューマ ノイドの跳躍やシリアルリンクロボットの跳躍に関する研究も 行われている [6] [7].

ヘビ型ロボットが他の跳躍ロボットと異なる点は, 前述した 体幹が持つ摩擦の異方性である。通常のヒューマノイド等の跳 躍では接地部分の摩擦はどの方向にも一様に働くと仮定される。 一方，へビ型ロボットは生物のへビと同様に体幹方向には摩擦 が小さく体幹と垂直方向には摩擦が大きいという特徵をもつた め, 接地したリンクに発生する摩擦の異方性を考慮した跳躍が 必要となる。

本研究では平面環境における三次元車輪拘束へビ型ロボット を対象に，横滑りせずに跳躍運動を行う制御則を提案する。ま ず対象とするへビ型ロボットの動力学モデルを導出し， ロボッ 卜と環境との間に働く床反力と摩擦力を考慮することで接地部 分が横滑りせずに跳躍運動を行う制御則を設計する，次に，跳 躍運動のための被制御量の目標値を設計し, 接地部分が横滑り しないための必要条件を導出する. さらに, 効果的な跳躍を行 うための評価指標として拘束力楕円とベース部重心角度を提案 し, 初期姿勢の最適化を行う。そして数值シミュレーションお よび物理シミュレータ Open Dynamics Engine [8] を用いたシ ミュレーションにより提案制御則の有効性を検証し，実機実験 により拘束力だ円に基づく評価指標の有効性を検証する.

\section{2. ヘビ型ロボットの動力学モデル}

制御対象として Fig. 1 に示したような $n$ リンクヘビ型ロボッ 卜を考える. 三次元的な運動を可能とするために各関節は 2 自 由度を有する能動ユニバーサルジョイントを想定する．初期姿 


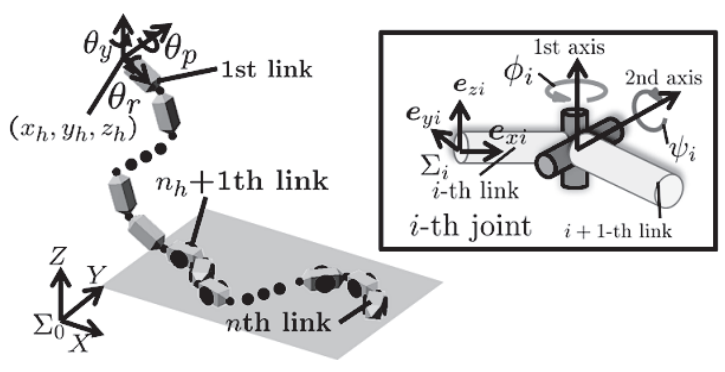

Fig. 1 A snake robot

勢において先頭からいくつかのリンクを持ち上げた状態を考え， ロボット先頭から $n_{h}$ リンクをへッド部, 第 $n_{h}+1$ リンクか ら第 $n$ リンクまでの環境と接触する $n_{b}$ リンクをベース部とし, 以下の仮定を導入する.

[仮定 1] 環境は平坦とする

[仮定 2] 接触は点接触に近似できる

[仮定 3] ヘッド部は環境と接しない

[仮定 4] ロボットはベース部の車輪によって支えられ, 跳躍運 動中ベース部車輪は常に環境に接する

[仮定 5] ベース部の車輪は横滑りしない

[仮定 6] 車輪はベース部すべてのリンクに配置する

仮定 1,2 は問題を簡略化するためのものである. 仮定 3,4 は 接触点が跳躍運動中に増減することでモデルが変化するケース を考慮しないためのものである. 仮定 5 はへビの「体幹と垂直 方向には滑らない」という摩擦の異方性を理想的に表現したも のである. また車輪配置条件についてへッド部とベース部を明確 に分けるためべース部先頭に車輪が存在し, すべての関節の運 動が被制御量の運動に寄与することを保証するためべース部最 後尾に車輪が存在する必要がある $[9]$. それ以外のベース部リン クについては，関節構成からベース部の車輪を外すことでベー ス部に運動学的圥長性を与えることができるものの, 車輪を外 すことによってベース部の支持点が少なくなり, 跳躍運動中の 安定性を保つ上で不利になる。また, 本研究では跳躍運動中の ベース部の運動を特に考えないので, 仮定 6 を導入しベース部 に運動学的冗長性はないものとする.

次に，一般化座標を定義する。絶対座標系 $\Sigma_{0}$ に関する口 ボット先頭の位置, 姿勢を $\boldsymbol{w}=\left[x_{h}, y_{h}, z_{h}, \theta_{r}, \theta_{p}, \theta_{y}\right]^{T}$, 第 $i$ 関節の第 1 回転軸まわりの回転角を $\phi_{i}$, 第 2 回転軸まわ りの回転角を $\psi_{i}$ と定義し, それらをまとめたべクトルを $\boldsymbol{\theta}_{i}=\left[\phi_{i}, \psi_{i}\right]^{T}$, 第 1 関節から第 $n-1$ 関節までをまとめた ベクトルを $\boldsymbol{\theta}=\left[\boldsymbol{\theta}_{1}^{T}, \cdots, \boldsymbol{\theta}_{n-1}^{T}\right]^{T}$ とする (Fig. 1 参照). そし て, 一般化座標を $\boldsymbol{q}=\left[\boldsymbol{w}^{T}, \boldsymbol{\theta}^{T}\right]^{T} \in R^{2 n+4}$ と定義する. また, 第 $i$ 関節の回転角 $\boldsymbol{\theta}_{i}$ に対応する関節トルクを $\boldsymbol{\tau}_{i}=\left[\tau_{\phi i}, \tau_{\psi i}\right]^{T}$, 第 1 関節から第 $n-1$ 関節までの入力トルクまとめたベクトル を $\boldsymbol{\tau}=\left[\boldsymbol{\tau}_{1}^{T}, \cdots, \boldsymbol{\tau}_{n-1}^{T}\right]^{T}$ とする. ロボットは離床時における ロボット全体の重心位置および速度によって一意に決まる放物 線運動を行うため, ロボットの重心速度を目標軌道に追従させ ることにより跳躍に必要な飛び出し速度を与える。また，ベー ス部先頭位置や姿勢が変化することを許容するとベース部が運 動中に後退したり, 特異姿勢に陥る可能性があるため, ベース

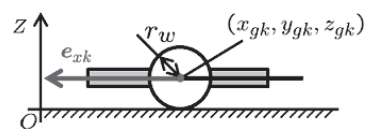

(a) Side view of the link

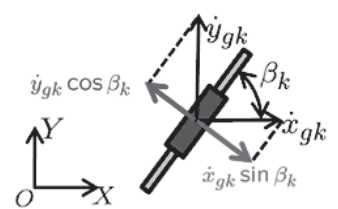

(b) Top view of the link
Fig. 2 The $k$-th link on $O-X Y$

部先頭位置と姿勢を制御することを考える。ここで, 被制御量 として $\overline{\boldsymbol{w}}=\left[\tilde{\boldsymbol{w}}^{T}, \boldsymbol{\theta}_{s c p}^{T}\right]^{T} \in R^{\left(n_{s c p}+7\right)}, \tilde{\boldsymbol{w}}=\left[\boldsymbol{r}_{g}^{T}, \boldsymbol{P}_{b h}^{T}\right]^{T}$ と する。ただし， $\boldsymbol{r}_{g}=\left[r_{g x}, r_{g y}, r_{g z}\right]^{T}$ はロボット全体の重心位 置, $\boldsymbol{P}_{b h}$ はロボットのベース部先頭である第 $n_{h}+1$ リンク の $X, Y$ 座標位置とロール, ピッチ回転角を並べたべクトルで あり, $\boldsymbol{P}_{b h}=\left[x_{n_{h}+1}, y_{n_{h}+1}, \theta_{r n_{h}+1}, \theta_{p n_{h}+1}\right]^{T}$ である. また， $\boldsymbol{\theta}_{s c p} \in R^{n_{s c p}}$ は運動学的圥長性に対応する関節角であり, 形状 可制御点と呼ばれる $[9][10]$.

\section{1 速度拘束式}

仮定 4,5 より車輪付きベース部リンクに働く速度拘束式を 導出する. Fig. 2 は第 $k$ リンクに車輪が取り付けられ, 環境で ある $O-X Y$ 平面に接している様子を表した図である。それ ぞれ，Fig. 2(a) はリンクの側面図, Fig. 2(b) はリンクの上面 図である，仮定が成り立つためには，Fig. $2(\mathrm{a})$ から車輪装着位 置 $\boldsymbol{P}_{g k}=\left[x_{g k}, y_{g k}, z_{g k}\right]^{T}$ が車輪半径 $r_{w}$ の高さに存在する必 要がある。 そのため, 次式が成り立つ。

$$
z_{g k}=r_{w}
$$

Fig. $2(\mathrm{~b})$ において, $\dot{x}_{g k}, \dot{y}_{g k}$ はそれぞれ第 $k$ リンク重心の絶 対座標系 $X, Y$ 軸方向速度, $\beta_{k}$ は第 $k$ リンクの絶対姿勢角の ヨー方向角度である. 仮定 4 が成り立つとき, 仮定 5 より次の 速度拘束式が得られる。

$$
\dot{x}_{g k} \cos \beta_{k}-\dot{y}_{g k} \sin \beta_{k}=0
$$

式（2）は，第 $k$ リンクの車輪が車軸方向に横滑りしないとい う非ホロノミック拘束である. 式（1）の時間微分と式（2）を 連立することで, 次の速度拘束式

$$
\overline{\boldsymbol{A}} \dot{\overline{\boldsymbol{w}}}=\overline{\boldsymbol{B}} \dot{\overline{\boldsymbol{\theta}}}
$$

を得る. ここで, $\overline{\boldsymbol{A}}=\left[\overline{\boldsymbol{A}}_{f}^{T}, \overline{\boldsymbol{A}}_{w}^{T}\right]^{T}, \overline{\boldsymbol{B}}=\left[\overline{\boldsymbol{B}}_{f}^{T}, \overline{\boldsymbol{B}}_{w}^{T}\right]^{T}$ であり, $\overline{\boldsymbol{A}}_{f} \in R^{n_{b} \times\left(n_{s c p}+7\right)}$ と $\overline{\boldsymbol{B}}_{f} \in R^{n_{b} \times 2 n_{b}}$ は式 (1) より得られ る行列, $\overline{\boldsymbol{A}}_{w} \in R^{n_{b} \times\left(n_{s c p}+7\right)}$ と $\overline{\boldsymbol{B}}_{w} \in R^{n_{b} \times 2 n_{b}}$ は式 $(2)$ よ り得られる行列である。 また, 関節角べクトル $\boldsymbol{\theta}$ から第 $n_{h}$ 番 めの関節から第 $n-1$ 関節までの関節角を抜き出し並べたべク トルを $\overline{\boldsymbol{\theta}}=\left[\boldsymbol{\theta}_{n_{h}}^{T}, \cdots, \boldsymbol{\theta}_{n-1}^{T}\right]^{T} \in R^{2 n_{b}}$ とする. 文献 $[10]$ より 運動学的圥長性の数は一般化座標の数からから被制御量と拘束 式の数を引いた数となる.よって, 一般化座標 $\boldsymbol{q}$ の数 $2 n+4$, 形状可制御点以外の被制御量 $\tilde{\boldsymbol{w}}$ の数 7 , 拘束式の数 $2 n_{b}$ より 運動学的冗長性の数は $n_{s c p}=2 n+4-7-2 n_{b}=2 n_{h}-3$ と なる。

\section{2 動力学モデル}

$\overline{\boldsymbol{B}}$ が可逆であると仮定すると, 速度拘束式（3）は次式のよ うに変形することができる。 


$$
\left[\begin{array}{ll}
-\overline{\boldsymbol{F}} & \boldsymbol{I}_{2 n_{b}}
\end{array}\right] \boldsymbol{T} \dot{\boldsymbol{q}}=\mathbf{0}
$$

ここで, $\overline{\boldsymbol{F}}=\overline{\boldsymbol{B}}^{-1} \overline{\boldsymbol{A}}, \boldsymbol{T} \in R^{(2 n+4) \times(2 n+4)}$ は一般化速度 $\dot{\boldsymbol{q}}$ をべクトル $\dot{\overline{\boldsymbol{q}}}=\left[\overline{\boldsymbol{w}}^{T}, \overline{\boldsymbol{\theta}}\right]^{T}$ に変換する行列であり, $\boldsymbol{T} \dot{\boldsymbol{q}}=\dot{\overline{\boldsymbol{q}}}$ で ある。速度拘束式（4）を考慮すると, へビ型ロボットの運動方 程式

$$
\boldsymbol{M}(\boldsymbol{q}) \ddot{\boldsymbol{q}}+\boldsymbol{h}(\boldsymbol{q}, \dot{\boldsymbol{q}})+\hat{\boldsymbol{g}}(\boldsymbol{q})+\boldsymbol{T}^{T}\left[\begin{array}{c}
-\overline{\boldsymbol{F}}^{T} \\
\boldsymbol{I}_{2 n_{b}}
\end{array}\right] \boldsymbol{\lambda}=\boldsymbol{E} \boldsymbol{\tau}
$$

を得る。ここで, $\boldsymbol{M} \in R^{(2 n+4) \times(2 n+4)}$ は慣性行列, $\boldsymbol{h} \in$ $R^{(2 n+4)}$ は遠心 · コリオリ力項, $\hat{g} \in R^{(2 n+4)}$ は重力項, $\lambda \in R^{2 n_{b}}$ はラグランジュの未定乗数, 行列 $\boldsymbol{E}$ は, $\boldsymbol{E}=$ $\left[\begin{array}{ll}\mathbf{0}_{2(n-1) \times 6} & \boldsymbol{I}_{2(n-1)}\end{array}\right]^{T} \in R^{(2 n+4) \times 2(n-1)}$ である. さらに, 式 （5）はラグランジュの未定乗数項を消去し, 拘束式 (3) を利用 することで, 状態量を $\overline{\boldsymbol{w}} に$ に低次元化した次式の運動方程式に 変形することができる.

$$
\bar{M} \ddot{\boldsymbol{w}}+\bar{h}=\bar{E} \tau
$$

ここで

$$
\begin{aligned}
& \overline{\boldsymbol{M}}=\left[\begin{array}{ll}
\boldsymbol{I}_{n_{s c p}+7} & \overline{\boldsymbol{F}}^{T}
\end{array}\right] \boldsymbol{T}^{-T} \boldsymbol{M} \boldsymbol{T}^{-1}\left[\begin{array}{c}
\boldsymbol{I}_{n_{s c p}+7} \\
\overline{\boldsymbol{F}}
\end{array}\right] \\
& \in R^{\left(n_{s c p}+7\right) \times\left(n_{s c p}+7\right)} \\
& \overline{\boldsymbol{h}}=\left[\begin{array}{ll}
\boldsymbol{I}_{n_{s c p}+7} & \overline{\boldsymbol{F}}^{T}
\end{array}\right] \boldsymbol{T}^{-T}(\boldsymbol{h}+\hat{\boldsymbol{g}})
\end{aligned}
$$

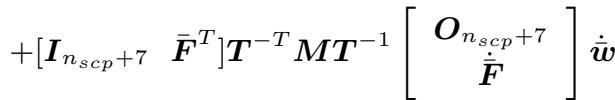

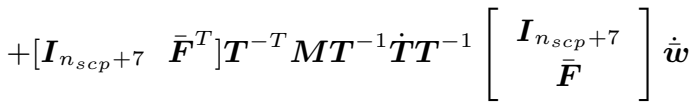

$$
\begin{aligned}
& \in R^{n_{s c p}+7} \\
& \overline{\boldsymbol{E}}=\left[\begin{array}{ll}
\boldsymbol{I}_{n_{s c p}+7} & \overline{\boldsymbol{F}}^{T}
\end{array}\right] \boldsymbol{T}^{-T} \boldsymbol{E} \in R^{\left(n_{s c p}+7\right) \times 2(n-1)}
\end{aligned}
$$

である，本研究では式（6）を動力学モデルとして扱い，関節卜 ルク $\boldsymbol{\tau}$ を入力とて跳躍制御則を設計する.

\section{3. 跳躍 運動制御}

\section{1 制御入力の設計}

動力学モデル（6）に対し, 制御入力 $\boldsymbol{\tau}$ を次式のように設計 する.

$$
\begin{aligned}
\boldsymbol{\tau} & =\boldsymbol{\tau}_{\min }+\boldsymbol{\tau}_{k e r} \\
& =\overline{\boldsymbol{E}}^{\dagger}\left(\overline{\boldsymbol{M}} \boldsymbol{\alpha}_{w}+\overline{\boldsymbol{h}}\right)+\overline{\boldsymbol{E}}_{k e r} \boldsymbol{\eta}
\end{aligned}
$$

ここで, $\boldsymbol{\alpha}_{w}=\ddot{\overline{\boldsymbol{w}}}_{d}+\boldsymbol{K}_{v}\left(\dot{\overline{\boldsymbol{w}}}_{d}-\dot{\dot{\boldsymbol{w}}}\right)+\boldsymbol{K}_{p}\left(\overline{\boldsymbol{w}}_{d}-\overline{\boldsymbol{w}}\right), \overline{\boldsymbol{E}}^{\dagger}$ は $\overline{\boldsymbol{E}}$ の擬似逆行列, $\overline{\boldsymbol{w}}_{d} \in R^{\left(n_{s c p}+7\right)}$ は被制御量の目標值ベクトル, $\boldsymbol{K}_{v}>0, \quad \boldsymbol{K}_{p}>0$ はゲイン行列, $\boldsymbol{\tau}_{k e r}=\overline{\boldsymbol{E}}_{k e r} \boldsymbol{\eta} \in \operatorname{Ker}(\overline{\boldsymbol{E}})$, $\overline{\boldsymbol{E}}_{k e r} \in R^{2(n-1) \times\left(2 n_{h}-6\right)}$ は $\overline{\boldsymbol{E}}$ の零空間の基底べクトルを列と する行列, $\boldsymbol{\eta} \in R^{\left(2 n_{h}-6\right)}$ は任意べクトルである. 入力 (7) の第 1 項 $\boldsymbol{\tau}_{\text {min }}$ は被制御量を目標軌道へ追従させるための入力であり, $\|\boldsymbol{\tau}\|$ を最小にする入力である. 第 2 項 $\boldsymbol{\tau}_{k e r}$ は被制御量 $\overline{\boldsymbol{w}}$ の運 動に影響を与えない入力であり, 動力学的午長性を表す入力であ る. 式 (3) より $\dot{\overline{\boldsymbol{\theta}}}=\overline{\boldsymbol{F}} \dot{\overline{\boldsymbol{w}}}$ の関係があるため, $\boldsymbol{\tau}_{k e r}$ はロボット全 体の運動にも影響を与えない.このとき, 動力学モデル（6）の閉 ループ系は, $\overline{\boldsymbol{M}}\left\{\left(\ddot{\ddot{\boldsymbol{w}}}-\ddot{\overline{\boldsymbol{w}}}_{d}\right)+\boldsymbol{K}_{v}\left(\dot{\overline{\boldsymbol{w}}}-\dot{\overline{\boldsymbol{w}}}_{d}\right)+\boldsymbol{K}_{p}\left(\overline{\boldsymbol{w}}-\overline{\boldsymbol{w}}_{d}\right)\right\}=\mathbf{0}$ となる. $\boldsymbol{T}, \bar{B}$ がフルランクであれば $\bar{M}>0$ となり,$t \rightarrow \infty$ で被制御量 $\overline{\boldsymbol{w}}$ は目標軌道 $\overline{\boldsymbol{w}}_{d}$ に収束する。

\section{2 横滑り回避}

ロボットが跳躍運動中に滑らずにロボット全体の重心に任意 の運動を与えるためには，接触点が滑らないような摩擦条件を 維持する必要がある。そのためには，ベース部に配置された各 車輪が横滑りしないよう, それぞれの車輪に扔いて摩擦条件が 満足されなければならない。 そこでロボットの動力学的午長性 を用いて車輪の横滑り回避を実現する制御入力を設計する.

車輪と環境との間に働く接触力は, 拘束力として導出するこ とが可能である，速度拘束式（3）を満たすためにロボットに働 かなければならない拘束力 $f \in R^{2 n_{b}}$ は仮想仕事の原理から導 くことができ，次式で与えられる.

$$
\boldsymbol{f}=\overline{\boldsymbol{B}}^{-T} \boldsymbol{\lambda}=\boldsymbol{X}(\boldsymbol{q}) \boldsymbol{\tau}+\boldsymbol{Y}(\boldsymbol{q}, \dot{\boldsymbol{q}})
$$

ここで

$$
\begin{gathered}
\boldsymbol{X}=\overline{\boldsymbol{B}}^{-T}\left(\boldsymbol{J} \boldsymbol{M}^{-1} \boldsymbol{J}^{T}\right)^{-1} \boldsymbol{J} \boldsymbol{M}^{-1} \boldsymbol{E} \\
\boldsymbol{Y}=-\overline{\boldsymbol{B}}^{-T}\left(\boldsymbol{J} \boldsymbol{M}^{-1} \boldsymbol{J}^{T}\right)^{-1}\left\{\boldsymbol{J} \boldsymbol{M}^{-1}(\boldsymbol{h}+\hat{\boldsymbol{g}})-\dot{\boldsymbol{J}} \dot{\boldsymbol{q}}\right\}
\end{gathered}
$$

であり, 行列 $\boldsymbol{J}$ は $\boldsymbol{J}=\left[\begin{array}{ll}-\overline{\boldsymbol{F}} & \boldsymbol{I}_{2 n_{b}}\end{array}\right] \boldsymbol{T}$ である. 第 $i(i=$ $\left.1, \cdots, n_{b}\right)$ 接触点における環境に垂直な方向の接触力を $f_{f i}$, 車軸方向の横拘束力を $f_{w i}$ とし, $\boldsymbol{f}_{f}=\left[f_{f 1}, \cdots, f_{f n_{b}}\right]^{T}$, $\boldsymbol{f}_{w}=\left[f_{w 1}, \cdots, f_{w n_{b}}\right]^{T}$ とすると, 拘束力 $\boldsymbol{f}$ は拘束式 (3) の構造との対応関係から $\boldsymbol{f}=\left[\boldsymbol{f}_{f}^{T}, \boldsymbol{f}_{w}^{T}\right]^{T}$ となる. よって, 接 触力 $\boldsymbol{f}_{f}, \boldsymbol{f}_{w}$ は

$$
\begin{gathered}
\boldsymbol{f}_{f}=\left(\boldsymbol{X}_{f} \boldsymbol{\tau}_{\text {min }}+\boldsymbol{Y}_{f}\right)+\boldsymbol{X}_{f} \boldsymbol{\tau}_{k e r} \\
\boldsymbol{f}_{w}=\left(\boldsymbol{X}_{w} \boldsymbol{\tau}_{\text {min }}+\boldsymbol{Y}_{w}\right)+\boldsymbol{X}_{w} \boldsymbol{\tau}_{k e r}
\end{gathered}
$$

と与えられる.ここで, $\boldsymbol{X}_{f} \in R^{n_{b} \times 2(n-1)}, \boldsymbol{Y}_{f} \in R^{n_{b}}$ は それぞれ $\boldsymbol{X}, \boldsymbol{Y}$ の 1 行めから $n_{b}$ 行め, $\boldsymbol{X}_{w} \in R^{n_{b} \times 2(n-1)}$ $\boldsymbol{Y}_{w} \in R^{n_{b}}$ はそれぞれ $n_{b}+1$ 行めから $2 n_{b}$ 行めである. 式 (9)，（10）より, 接触力 $\boldsymbol{f}_{f}, \boldsymbol{f}_{w}$ は関節トルクによって一意に 決まることが分かる.

接触点に扔ける摩擦をクーロン摩擦で表すと, 第 $i$ 車輪が横 滑りしないための条件は $\left|f_{w i}\right| \leq \mu f_{f i}$ で与えられるが，等号が 成り立つ場合にわずかな外乱によって滑りが生じてしまうため, 余裕 $\epsilon \geq 0$ を与えた次式を第 $i$ 車輪が横滑りしないための条件 として扱う。

$$
\left|f_{w i}\right| \leq \mu f_{f i}-\epsilon
$$

ここで, $f_{f i}<0$ となるときは環境とロボット間で張力が㗢く という物理的にあり得ないケースであるため, $f_{f i}>0$ という 制約を加えて条件（11）を書き直すと次式を得る. 


$$
\left\{\begin{array}{l}
-\mu f_{f i}+\epsilon \leq f_{w i} \\
f_{w i} \leq \mu f_{f i}-\epsilon \\
f_{f i}>0
\end{array}\right.
$$

条件 (12) を式 (9)，（10）と $\boldsymbol{\tau}_{k e r}=\overline{\boldsymbol{E}}_{k e r} \boldsymbol{\eta}$ の関係を用いて 変形すると, 次式の $\boldsymbol{\eta}$ についての制約条件を得る.

$$
\boldsymbol{A}_{l} \boldsymbol{\eta} \leq \boldsymbol{b}_{l}
$$

ここで, $\boldsymbol{A}_{l} \in R^{3 n_{b} \times\left(2 n_{b}-6\right)}, \boldsymbol{b}_{l} \in R^{3 n_{b}}$ である.この制約条件 （13）を満たす $\boldsymbol{\tau}_{k e r}=\overline{\boldsymbol{E}}_{k e r} \boldsymbol{\eta}$ の任意ベクトル $\boldsymbol{\eta}$ を与えること で，車輪の横滑りを回避することを考える，跳躍には大きな卜

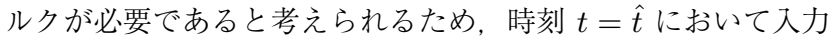
トルクを最小化する次式の二次計画問題を考える.

$$
\min _{\boldsymbol{\eta}} \frac{1}{2} \boldsymbol{\tau}(\hat{t})^{T} \boldsymbol{\tau}(\hat{t})=\frac{1}{2} \boldsymbol{\eta}(\hat{t})^{T} H \boldsymbol{\eta}(\hat{t})
$$

$$
\text { subject to equation (13) }
$$

制御対象に入力を与える各離散時刻で最適化問題（14）を解き, $\boldsymbol{\tau}_{k e r}=\overline{\boldsymbol{E}}_{k e r} \boldsymbol{\eta}$ として与えれば，摩擦条件が満たされる.

\section{3 最適化問題（14）の解の必要条件}

制約条件付き最適化問題（14）の解の存在条件について考え る.この最適化問題の可解性は一般的には証明することができ ないため, 本論文では力学的観点から, 解が存在する必要条件 についてのみ考える

式（11） から, 床反力の総和 $\boldsymbol{F}_{f}=\sum_{i=1}^{n_{b}} f_{f i}$ と横拘束力の 絶対值の総和 $\boldsymbol{F}_{w}=\sum_{i=1}^{n_{b}}\left|f_{w i}\right|$ は

$$
\boldsymbol{F}_{w} \leq \mu \boldsymbol{F}_{f}-n_{b} \epsilon
$$

となることが最適化問題が可解となる必要条件である。ここで， 床反力の総和 $\boldsymbol{F}_{f}$ はロボット全体の重心にかかる慣性力の $Z$ 軸 方向成分と等しくなるため，次式のように表される.

$$
\boldsymbol{F}_{f}=\boldsymbol{F}_{z}=\left(\ddot{r}_{g z}+g\right) \sum_{i=1}^{n} m_{i}
$$

ただし， $\ddot{r}_{g z}$ はロボット全体の重心加速度の $Z$ 軸方向成分, $g$ は重力加速度, $m_{i}$ は第 $i$ リンクの質量である。 また, 各車輪 に発生する横拘束力はロボット全体の重心にかかる慣性力の水 平方向成分 $\boldsymbol{F}_{x y}$ に関係する. 慣性力 $\boldsymbol{F}_{x y}$ を跳躍方向成分とそ れに垂直な成分をそれぞれ $\boldsymbol{F}_{x}, \boldsymbol{F}_{y}$ とすると，それぞれ

$$
\boldsymbol{F}_{x}=\sum_{i=1}^{n_{b}} f_{w x i}, \quad \boldsymbol{F}_{y}=\sum_{i=1}^{n_{b}} f_{w y i}
$$

となる．ここで, $f_{w x i}, f_{w y i}$ はそれぞれ, 第 $i$ リンクに発生す る横拘束力 $f_{w i}$ を跳躍方向とそれに垂直な成分に分けたもので ある. また, 慣性力 $F_{x}, F_{y}$ はそれぞれ, 床面に水平な跳躍方 向の加速度 $\ddot{r}_{g x}$ とそれに垂直な方向の加速度 $\ddot{r}_{g y}$ から

$$
\boldsymbol{F}_{x}=\ddot{r}_{g x} \sum_{i=1}^{n} m_{i}, \quad \boldsymbol{F}_{y}=\ddot{r}_{g y} \sum_{i=1}^{n} m_{i}
$$

と表すことができる. 式（18）から重心加速度によって慣性力

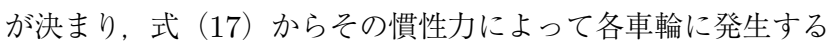

横拘束力は

$$
\begin{aligned}
& \boldsymbol{F}_{x}=\ddot{r}_{g x} \sum_{i=1}^{n} m_{i}=\sum_{i=1}^{n_{b}} f_{w x i} \\
& \boldsymbol{F}_{y}=\ddot{r}_{g y} \sum_{i=1}^{n} m_{i}=\sum_{i=1}^{n_{b}} f_{w y i}
\end{aligned}
$$

とならなければならない。ここで,

$$
\boldsymbol{F}_{w} \geq \boldsymbol{F}_{x y}
$$

となる.ただし, $\boldsymbol{F}_{x y}=\sqrt{\boldsymbol{F}_{x}^{2}+\boldsymbol{F}_{y}^{2}}$ である. 式 (21) を式 （15）に代入すると,

$$
\boldsymbol{F}_{x y} \leq \boldsymbol{F}_{w} \leq \mu \boldsymbol{F}_{f}-n_{b} \epsilon
$$

となる. $\sum_{i=1}^{n} m_{i}=m_{\text {all }}$ とすると, 式 (16), (18), (22) から,

$$
\sqrt{\ddot{r}_{g x}^{2}+\ddot{r}_{g y}^{2}} \leq \mu\left(\ddot{r}_{g z}+g\right)-\frac{n_{b}}{m_{a l l}} \epsilon
$$

となるように重心加速度の目標軌道を設計する必要がある。た だし，式（23）は最適化問題が可解であるための必要条件であ り, 必要十分条件でないことに注意されたい. 必要十分条件の 解明については今後の課題とする.

\section{4 被制御量の目標軌道}

問題を簡単化するため, 跳躍運動においてベース部は運動を 行わず横滑りしないよう体を支えるのに用い, ヘッド部の運動 によって跳躍の運動量を得ることにする。ベース部先頭位置・姿 勢 $\boldsymbol{P}_{b h}$ の目標值は初期位置および姿勢を維持するよう $\boldsymbol{P}_{b h}(0)$ とする。

次に，ロボットの重心 $\boldsymbol{r}_{g}$ の目標軌道 $\boldsymbol{r}_{g d}$ を設計する。ロボッ トは接地状態にて運動量をため, 離床時に重心の加速度を 0 に するよう動作することで跳躍できる. 本研究では目標重心加速 度 $\ddot{\boldsymbol{r}}_{g d}$ を正弦波を用いて次式のように与える.

$$
\ddot{\boldsymbol{r}}_{g d}=[b x, b y, b z]^{T} \sin \left(\frac{\pi}{t_{f}} t\right)
$$

ここで, $t_{f}$ は離床時刻, $b x, b y, b z$ は運動中の重心の最大加速 度であり，前述の必要条件（23）を満たすよう設計する.

形状可制御点の目標值としてはロボットの動力学モデルの特 異点回避を考える. 特異点回避は運動学的圥長性を表す形状可 制御点の目標值 $\boldsymbol{\theta}_{\text {scpd }}$ を適切に設計することで実現できる [10]. 動力学モデルにおいて, 逆行列を必要とする行列は $\boldsymbol{T}$ と $\bar{B}$ で あり, これら二つの行列がランク落ちした場合, 入力が発散し てしまう。 そこで，これらの行列の行列式の值から評価関数 $\boldsymbol{V}$ を求め, $\boldsymbol{V}$ を増大化する形状可制御点の目標值を与える。 まず, 評価関数 $\boldsymbol{V}(\boldsymbol{q})$ を次のように設定する.

$$
\boldsymbol{V}(\boldsymbol{q})=a \operatorname{det}\left(\overline{\boldsymbol{B}}^{T} \overline{\boldsymbol{B}}\right)+b \operatorname{det}\left(\boldsymbol{T}^{T} \boldsymbol{T}\right)
$$

ここで, $a, b>0$ は重み係数である. 評価関数 $\boldsymbol{V}$ を増大化す ることで動力学モデルの特異点を回避することができる。ここ で，Vの時間微分を計算すると 


$$
\begin{aligned}
& \dot{V}=\frac{\partial V}{\partial \boldsymbol{q}} \dot{\boldsymbol{q}}=\frac{\partial V}{\partial \boldsymbol{q}} \boldsymbol{T}^{-1} \dot{\overline{\boldsymbol{q}}}=\frac{\partial V}{\partial \boldsymbol{q}} \boldsymbol{T}^{-1}\left[\begin{array}{c}
\dot{\boldsymbol{w}} \\
\dot{\overline{\boldsymbol{\theta}}}
\end{array}\right] \\
& =\frac{\partial V}{\partial \boldsymbol{q}} \boldsymbol{T}^{-1}\left[\begin{array}{c}
\dot{\overline{\boldsymbol{w}}} \\
\overline{\boldsymbol{F}} \dot{\overline{\boldsymbol{w}}}
\end{array}\right]=\frac{\partial V}{\partial \boldsymbol{q}} \boldsymbol{T}^{-1}\left[\begin{array}{c}
\boldsymbol{I} \\
\overline{\boldsymbol{F}}
\end{array}\right] \dot{\overline{\boldsymbol{w}}} \\
& =\frac{\partial V}{\partial \boldsymbol{q}} \overline{\boldsymbol{F}}_{T 1} \dot{\tilde{\boldsymbol{w}}}+\frac{\partial V}{\partial \boldsymbol{q}} \overline{\boldsymbol{F}}_{T 2} \dot{\overline{\boldsymbol{\theta}}}_{s c p} \\
& {\left[\begin{array}{ll}
\overline{\boldsymbol{F}}_{T 1} & \overline{\boldsymbol{F}}_{T 2}
\end{array}\right]=\boldsymbol{T}^{-1}\left[\begin{array}{c}
\boldsymbol{I} \\
\overline{\boldsymbol{F}}
\end{array}\right]}
\end{aligned}
$$

を得る。よって, 形状可制御点の目標值 $\boldsymbol{\theta}_{\text {scpd }}$ を

$$
\dot{\boldsymbol{\theta}}_{s c p d}=\boldsymbol{K}_{s c p}\left(\frac{\partial V}{\partial \boldsymbol{q}} \overline{\boldsymbol{F}}_{T 2}\right)^{T}
$$

と与える.ここで, $\boldsymbol{K}_{s c p} \geq 0$ は重み行列である. $\dot{\boldsymbol{\theta}}_{s c p}=\dot{\boldsymbol{\theta}}_{s c p d}$ となれば式（26）の第 3 式第 2 項が正となるため, 重み行列 $\boldsymbol{K}_{s c p}$ を適切に決定することで評価関数 $V$ の増大化, すなわち 特異姿勢回避に貢献できる $[10]$.

\section{4. ベース部初期姿勢}

ヘビ型ロボットは摩擦の異方性という特徴をもつため, 初期 姿勢が跳躍運動に与える影響が大きい. 本章では跳躍運動に適 したべース部初期姿勢を選ぶための評価指標を提案する。

\section{1 拘束力だ円}

ヘビ型ロボットの跳躍運動ではベース部のみで跳躍に耐えう る摩擦力を生み出す必要がある.ヘッド部の運動によって生じ る力はベース部の先頭からベース部全体に伝わっていく，そこ で, ベース部先頭に発生する力とベース部各車輪に発生する最 大摩擦力の関係を求める.

ヘッド部を無視し、ベース部における第 2 回転軸まわりの 回転角がすべてゼロであるとすると, 制御対象は二次元へビ 型ロボットと等価なモデルとなる. ベース部先頭関節のヨー回 転角を $\theta_{y n_{h}+1}, \boldsymbol{\theta}_{b}=\left[\theta_{y n_{h}+1}, \phi_{n_{h}+1}, \cdots, \phi_{n-1}\right]^{T}, \boldsymbol{w}_{b}=$ $\left[x_{n_{h}+1}, y_{n_{h}+1}\right]^{T}$ とすると, 速度拘束式 (2) は

$$
\boldsymbol{A}_{w} \dot{\boldsymbol{w}}_{b}=\boldsymbol{B}_{w} \dot{\boldsymbol{\theta}}_{b}
$$

と表すことができる，さらに，ベース部の各関節の速度，加速 度を 0 とすると, ベース部に㧍ける力の関係は次式で表され る [11].

$$
\boldsymbol{J}_{w}^{T} \boldsymbol{B}_{w}^{T} \boldsymbol{f}_{w}=\boldsymbol{E}_{b} \boldsymbol{\tau}_{b}+\boldsymbol{Q} \boldsymbol{f}_{n_{h} x y}
$$

ここで, ベース部各関節ヨー方向回転入力トルクを並べたベクト 儿を $\boldsymbol{\tau}_{b}=\left[\tau_{\phi_{n_{h}}}, \cdots, \tau_{\phi_{n-1}}\right]^{T}$, ベース部先頭に働く力を $\boldsymbol{f}_{n_{h} x y}$ とし, $\boldsymbol{J}_{w}=\left[-\boldsymbol{B}_{w}^{-1} \boldsymbol{A}_{w}, \quad \boldsymbol{I}_{n_{b}}\right], \quad \boldsymbol{E}_{b}=\left[O_{3 \times\left(n_{b}-1\right)}^{T}, I_{n_{b}-1}\right]^{T} \in$ $R^{\left(n_{b}+2\right) \times\left(n_{b}-1\right)}, \quad \boldsymbol{Q}=\left[I_{2}, O_{n_{b} \times 2}^{T}\right]^{T} \in R^{n_{b} \times 2}$ である. $\boldsymbol{B}_{w}$ は 全リンクに車輪をもつ二次元へビ型ロボット [2] と同様に常に可 逆である. $\boldsymbol{E}_{b} \boldsymbol{\tau}_{b}$ の 1, 2 行めはすべて 0 であるので, 式 (29) の 1,2 行めを抜き出して変形すると

$$
\begin{gathered}
\boldsymbol{f}_{n_{h} x y}=\boldsymbol{P} \boldsymbol{f}_{w} \\
\boldsymbol{P}=-\boldsymbol{A}_{w}^{T}
\end{gathered}
$$

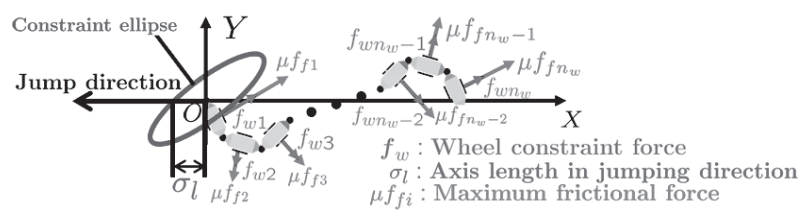

Fig. 3 Definition of $\sigma_{l}$

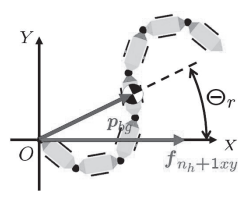

Fig. 4 Definition of $\Theta_{r}$

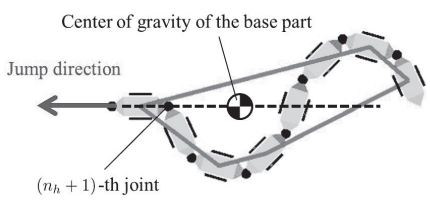

Fig. 5 Adjustment of $\Theta_{r}$
を得る.この横拘束力 $\boldsymbol{f}_{w}$ は車輪と床面間の最大摩擦力によっ て制限される，第 $i$ 番めリンクの横方向最大摩擦力の大きさを $f_{\mu \max i}$ とすると, ベース部先頭に与えることができる $\boldsymbol{f}_{n_{h} x y}$ は式（30）より

$$
\boldsymbol{f}_{n_{h} x y}=\boldsymbol{P} \boldsymbol{N} \hat{\boldsymbol{f}}_{w}
$$

となる.ここで, $N, \hat{f}$ は

$$
\begin{gathered}
\boldsymbol{N}=\operatorname{diag}\left(f_{\mu \max 1}, f_{\mu \max 2}, \cdots, f_{\mu \max n_{w}}\right) \\
\hat{\boldsymbol{f}}_{w}=\left[\hat{f}_{w 1}, \hat{f}_{w 2}, \cdots, \hat{f}_{w n_{w}}\right]^{T}, \quad \hat{f}_{w i}=f_{w i} / f_{\mu \max i}
\end{gathered}
$$

であり， $f_{\mu \max i}$ は式（9）功求まる各車輪にかかる垂直抗力 $f_{f i}$ と摩擦係数 $\mu$ を用いて $f_{\mu \max i}=\mu f_{f i}$ で算出される. ここで $\boldsymbol{P} \boldsymbol{N}$ を特異值分解し, 特異値 $\sigma_{1}, \sigma_{2}$ と直交行列 $U=\left[\boldsymbol{u}_{1}, \boldsymbol{u}_{2}\right]$ から $X Y$ 平面上にFig. 3 のようなだ円を得る。だ円の主軸は $\sigma_{1} \boldsymbol{u}_{1}, \sigma_{2} \boldsymbol{u}_{2}$ で与えられる。 $\sigma_{1} \boldsymbol{u}_{1}$ はだ円長軸， $\sigma_{2} \boldsymbol{u}_{2}$ はだ円短 軸を表している。 また, 長軸方向の力に対しロボットは滑らず 最も耐えられることを意味しており，このだ円を拘束力だ円と 呼ぶ．跳躍時の横滑りに影響するのは跳躍方向の拘束力である ことから，だ円の跳躍方向軸長さ $\sigma_{l}$ を評価指標とする， $\sigma_{l}$ の 值が大きいほど跳躍に適した初期姿勢であると考えられる.

な押, 式 (31) 功分かるように $\sigma_{l}$ は正規化された横拘束力 $\hat{\boldsymbol{f}}_{w} \leq 1$ における值である. 実際のロボットでは, 横滑りしない 場合に $\hat{\boldsymbol{f}}_{w}$ の各成分 $\hat{f}_{1}, \cdots, \hat{f}_{n_{w}} \leq 1$ となるため, $\hat{\boldsymbol{f}}_{w} \leq \sqrt{n_{w}}$ である。以上より, ベース部先頭においてロボットが横滑りせ ずに耐えられる跳躍方向の最大の力 $f_{b}$ は次式で計算できる.

$$
f_{b}=\sigma_{l} \sqrt{n_{w}}
$$

\section{2 ベース部重心角度}

ベース部に掠いて，Fig.4 のようにヘッド部から受ける力 $\boldsymbol{f}_{n_{h}+1 x y}$ とベース部先頭とベース部重心を結ぶベクトル $\boldsymbol{p}_{b g}$ が 一致せず，角度 $\Theta_{r}$ を持つとする。この場合，ベース部重心回り のモーメント $\tau_{b c o g}=\left|\boldsymbol{f}_{n_{h}+1 x y}\right| \cos \Theta_{r}$ が発生する. ベース部 が滑らないためには，このモーメントに対してベース部重心回 りに回転しないように耐える必要がある。すすなわ，このモー メントが大きいほどベース部に負荷がかかることになる。 $\Theta_{r}$ は $\boldsymbol{p}_{b g}$ と $\boldsymbol{f}_{n_{h}+1 x y}$ より, 


$$
\Theta_{r}=\cos ^{-1}\left(\frac{\boldsymbol{f}_{n_{h}+1 x y} \cdot \boldsymbol{p}_{b g}}{\left|\boldsymbol{f}_{n_{h}+1 x y}\right|\left|\boldsymbol{p}_{b g}\right|}\right)
$$

と表すことができる。この $\Theta_{r}$ の小さいベース部形状ほど跳躍 に適していると考えられる。

\section{3 評価関数}

本論文では，Fig. 5 に示すように跳躍方向とベース部重心位 置とが同一直線上となるよう $\phi_{n_{h}+1}$ を与えることにより，モー メントによってベース部にかかる負荷を抑えることにする。 こ れにより，すべての姿勢について $\Theta_{r}=0$ とすることができる. そして, ベース部初期姿勢を決定するための評価関数 $\boldsymbol{V}_{b}$ を

$$
\boldsymbol{V}_{b}=\sigma_{l}
$$

とし, 評価関数を最大とする初期姿勢をべース部初期姿勢とし て選択する。

\section{5. シミュレーション}

前章までに設計した制御則および提案した初期姿勢決定の評 価指標の有効性を数值シミュレーションにより検証する. 制御 対象として $n=16$ の 16 リンクヘビ型ロボットを用いる. ヘッ ド部のリンク数は $n_{h}=8$, ベース部のリンク数は $n_{b}=8$ とし, ヘッド部に運動学的冗長性 $n_{s c p}=13$ がある.ここでは形状可 制御点として第 1 関節から第 6 関節の自由度と第 7 関節の第 1 軸まわりの自由度を選択し, $\boldsymbol{\theta}_{s c p}=\left[\boldsymbol{\theta}_{1}^{T}, \cdots, \boldsymbol{\theta}_{6}^{T}, \phi_{7}\right]^{T}$ とした。 また, リンク長さを $2 l=0.15[\mathrm{~m}]$, 質量を $m=0.5[\mathrm{~kg}]$, 車輪 と環境間の静止摩擦係数を $\mu=0.8$ とした. ロボットのベース 部とへッド部の間の関節（第 $n_{h}$ 関節）が絶対座標系 $O-X Y Z$ の原点に存在するとし, 跳躍方向は $X$ 軸負の方向, ベース部を 除く関節角の初期值は $\left[\boldsymbol{\theta}_{1}, \cdots, \boldsymbol{\theta}_{n h}\right]^{T}=[0,2.4,0,0,0,-2.4$, $0,0,0,2.4,0,0,0,-1.6,0,-1.0]^{T}$ とした.

\section{1 ベース部初期姿勢の最適化}

ベース部の初期姿勢はへビのサーペノイド曲線 [1] を規範とし ていると仮定する。サーペノイド曲線とはへビの蛇行滑走体形 曲線を表した曲線であり，体長（リンク数と各リンク長さ）が 既知であればくねり角度 $\alpha_{b}$ とくねり周期 $T_{b}$ により形状を決 定することができる。本論文では

$$
\phi_{i}=\frac{2 \pi T_{b}}{n_{b}-1} \alpha_{b} \sin \left(\frac{2 \pi T_{b}}{n_{b}}\left(i-n_{h}-1\right)\right), \quad \psi_{i}=0
$$

第 $n_{h}+1$ リンクの関節角については, $\psi_{n_{h}+1}=0$ とし, $\phi_{n_{h}+1}$ は前節で説明したようにベース部重心角度 $\Theta_{r}=0$ となるよう 与える.

ベース部に関する各パラメータに対して, ベース部くねり角 度 $\alpha_{b}$ を $0.1 \leq \alpha_{b} \leq 4[\mathrm{rad}]$ の範囲で $0.01[\mathrm{rad}]$ 刻みで, ベー ス部くねり周期 $T_{b}$ を $0.1 \leq T_{b} \leq 2.5$ の範囲で 0.01 刻みで離 散的に変化させ, 各姿勢における評価関数 $\boldsymbol{V}_{b}$ の值を導出した。 この際, 実ロボットにおける可動範囲を考慮し, 制約条件とし て $\left|\phi_{i}\right| \leq \pi / 2$ を満たす姿勢のみ計算を行った. $T_{b}, \alpha_{b}$ と評価 関数 $\boldsymbol{V}_{b}$ の関係を Fig. 6 に示す. 評価関数が最大となったの は Fig. 7 に示す $T_{b}=1.17, \alpha_{b}=1.69[\mathrm{rad}]$ の場合であった. よって, この姿勢をべース部初期姿勢として用いることにする。

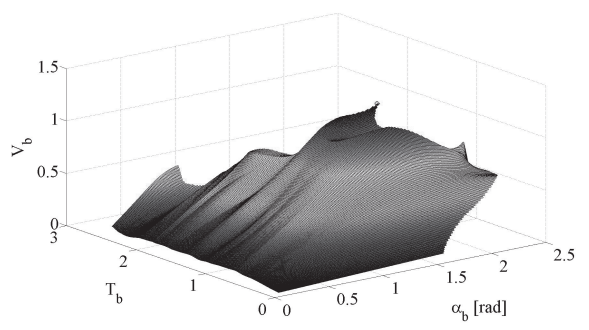

Fig. 6 Value of the cost function $\boldsymbol{V}_{b}$

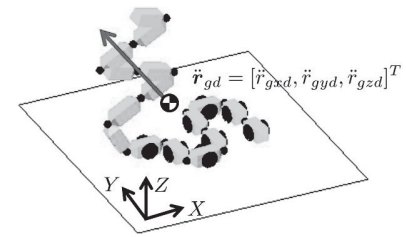

Fig. 7 Optimal posture of the base part

\section{2 跳躍シミュレーション}

制御則の有効性を検証するため跳躍シミュレーションを行う. まず横滑りが生じない式（6）の動力学モデルを用いて Matlab 上でシミュレーションを行い, 重心位置等の時間応答と制御入 力を確認する. なお, 制約条件付き最適化問題 (14) の数值解 法として Matlab の二次計画問題のソルバ quadprog.m を用い, 余裕 $\epsilon=1.0[\mathrm{~N}]$ とした. 次に, 得られた制御入力を物理シミュ レータ Open Dynamics Engine (ODE) 上に構築したへビ型 ロボットに入力する. ODE 上のへビ型ロボットは, 過度な力が かかった場合に横滑りが生じるモデルとなっており，実ロボッ トにおける跳躍の実現性を確認できる。ODEにおいては，本 研究では跳躍運動後の浮遊中の運動制御を行わないため, 離床 時刻となった時点でロボットの各関節を幾何学的に固定した。

ベース部初期姿勢として, 最適姿勢 $\left(T_{b}=1.17, \alpha_{b}=\right.$ $1.69[\mathrm{rad}])$ と最適ではない姿勢 $\left(T_{b}=1.17, \alpha_{b}=0.5[\mathrm{rad}]\right)$ の 2 とおりについてシミュレーションを行った。重心加速度 に関するパラメータについては必要条件（23）を満たすよう $t_{f}=0.15[\mathrm{~s}], b x=-8, b y=0, b z=10$ とし, $\boldsymbol{K}_{p}=\operatorname{diag}(10$, $10,10,100,10,10,10,1,1,1,1,1,1,1,1,1,1,1,1,1)$, $\boldsymbol{K}_{v}=\operatorname{diag}(20,20,20,500,200,200,200,1,1,1,1,1,1,1$, $1,1,1,1,1,1), \boldsymbol{K}_{s c p}=\operatorname{diag}(0,2,400,0,60,0,12,0,12,0$, 120, 0, 12, 0) とした. また, 今回用いたパラメータでは $\boldsymbol{T}$ の ランク落ちは起こらなかったため, 形状可制御点に関する重み 係数 $b=0$ とし， $a$ についてはリンク長さの $1 / 2$ である $l$ で 正規化し $, a=a^{\prime} / l^{32}, a^{\prime}=1.0$ とした.

ベース部初期姿勢を最適姿勢 $T_{b}=1.17, \alpha_{b}=1.69[\mathrm{rad}]$ と した場合について，横滑りが生じないモデルを用いた結果の一 部を Fig. 8, 9, 10 に示す。なお, 重心位置は目標軌道に追従 することを確認したが，図については誌面の都合上省略する． Fig. 8 は跳躍運動中の $\operatorname{det} \overline{\boldsymbol{B}}^{T} \overline{\boldsymbol{B}} / l^{32}$ と $\operatorname{det} \boldsymbol{T}^{T} \boldsymbol{T}$ の時間応答で ある.どちらの值も 0 には収束しておらず，特異姿勢を回避で きている. Fig. 9 は摩擦条件に関する $\mu f_{f i}-\left|f_{w i}\right|$ の時間応答 である。摩擦条件を満たしていない場合は $\mu f_{f i}-\left|f_{w i}\right|$ が負 となる. Fig. 9 より, 常に $\mu f_{f i}-\left|f_{w i}\right|$ が正となるよう運動し ており, 摩擦条件を満足していることが分かる. Fig. 10 は跳 

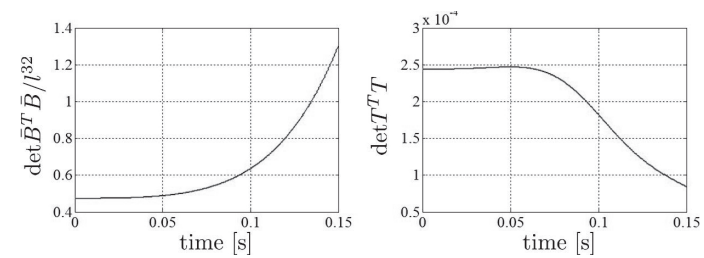

Fig. 8 Time responses of $\operatorname{det} \overline{\boldsymbol{B}}^{T} \overline{\boldsymbol{B}} / l^{32}$ and $\operatorname{det} \boldsymbol{T}^{T} \boldsymbol{T}$ based on the model without sliding
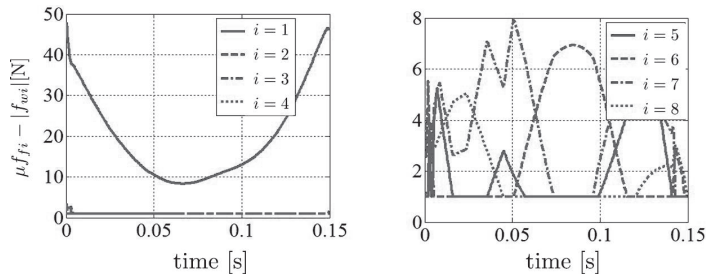

Fig. 9 Time responses of $\mu f_{f i}-\left|f_{w i}\right|$ based on the model without sliding
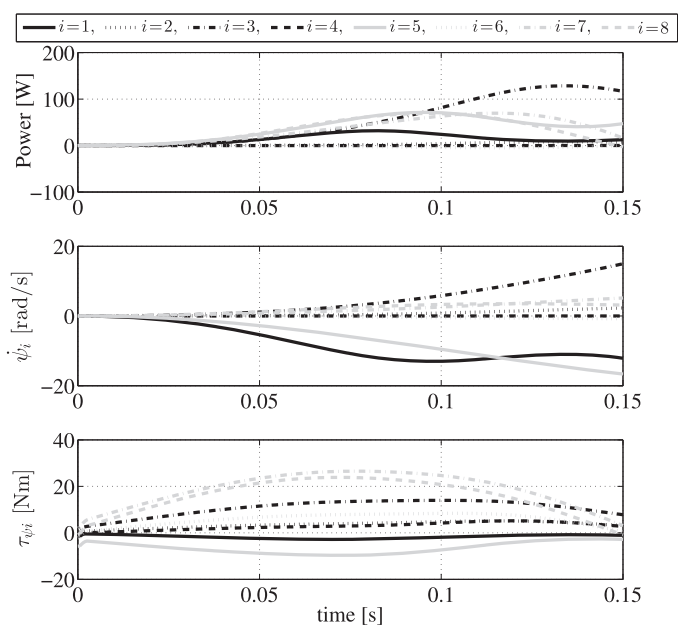

Fig. 10 The power, angular velocity and torque of $\psi_{i}$

躍動作時に大きく駆動しているヘッド部第 2 回転軸まわりの回 転角 $\psi_{i}\left(i=1, \cdots, n_{h}\right)$ に対するアクチュエータトルク, 回転 速度, アクチュエータ出力である。 シミュレーションに怙ける $m=0.5[\mathrm{~kg}], 2 l=0.15[\mathrm{~m}]$ というロボットの大きさに対し，ア クチュエータ出力が最大で $130[\mathrm{~W}]$ に達していることが分かる. 減速機や構造部材の質量や効率を考えると, 現存する電磁モー 夕を用いたへビ型ロボットの跳躍動作の実現は非常に難しいと 言える. 跳躍動作の実現方法としては例えば出力質量比が高い 空気圧アクチュエータの利用が挙げられるが，これは今後の課 題とする.

次に, ODE において横滑りが生じるモデルを用いた結果を Fig. 11，12 に示す. Fig. 11 は $t=0,0.10,0.15,0.20,0.25$, $0.339[\mathrm{~s}]$ のロボットの動作の様子を表している. 誌面水平方向 が $X$ 軸, 鉛直方向が $Z$ 軸であり, 点線は $t=0$ に抢けるべー 久部先頭リンク中心の $X$ 座標位置を表しており, $t=0.15[\mathrm{~s}]$ は離床時刻, $t=0.20,0.25[\mathrm{~s}]$ は浮遊期, $t=0.339$ [s] は着 床時刻のロボットの様子である. Fig. 12 は初期時刻から着床 時刻までの重心位置 $\boldsymbol{r}_{g}$, ベース部先頭位置姿勢 $\boldsymbol{P}_{b h}$ の応答

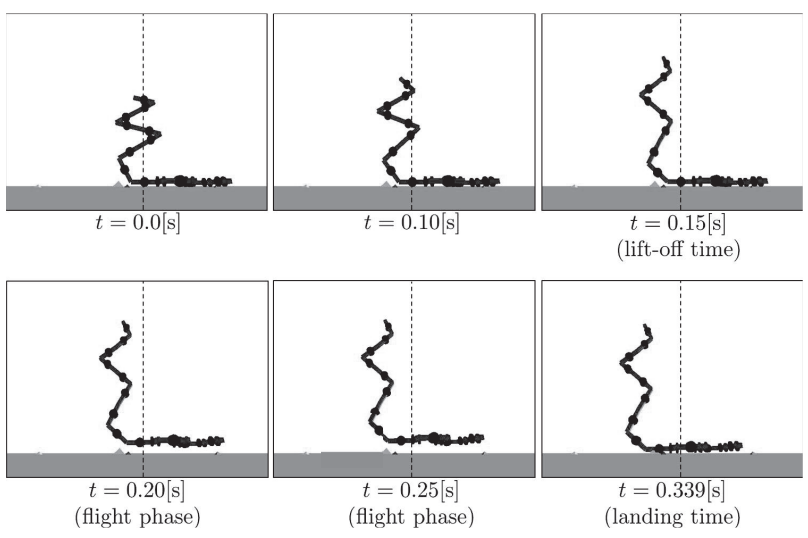

Fig. 11 The motion of the snake robot in ODE
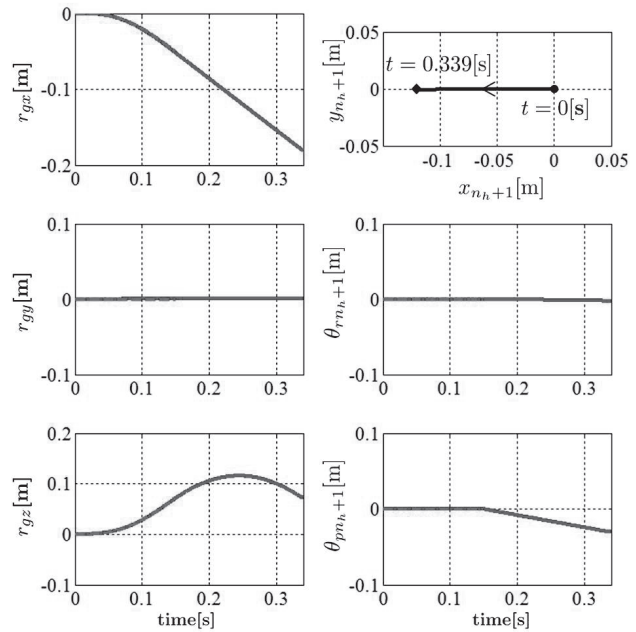

Fig. 12 Simulation results in ODE

を表している。点線は目標軌道を表しており, 制御は離床時刻 $t=0.15[\mathrm{~s}]$ まで行っているため, 目標軌道も離床時刻までを表 示している. $x_{n_{h}+1}, y_{n_{h}+1}$ のグラフは, 初期ベース部先頭位置 を丸印 $(t=0[\mathrm{~s}])$, 着床地点をひし形 $(t=0.339[\mathrm{~s}])$ で表し ている. Fig. 12 より, 離床時刻まで各状態量が目標軌道に追従 しているとともに, ベース部先頭位置 $x_{n_{h}+1}, y_{n_{h}+1}$ が跳躍運 動中後方へ滑らずに離床していることが分かる．以上のように, ベース部が滑ることなく跳躍を実現できており, 提案制御則の 有効性が確認できた.

一方, 各パラメー夕は変えずにベース部初期姿勢のみを最適 でない姿勢 $T_{b}=1.17, \alpha_{b}=0.5[\mathrm{rad}]$ に変更した場合, 制御入 力の計算に执いて最適化問題（14）の解が存在せずに摩擦条件 を満足できないことが確認された. ODEを用いて行ったシミュ レーション結果を Fig. 13 に示す. 離床時刻前にベース部が後 方へ滑ってしまい, いくつかのベース部車輪がすでに地面を離 れてしまっている。 これは, 最適なべース部初期姿勢と比較し 評価関数の值が低い，すなわち跳躍方向に耐えられる力が弱い ことが原因であると言える. 以上より, 接地部の横滑り回避に は拘束力楕円を用いた姿勢決定が有効であると考えられる.

\section{3 大跳躍}

本手法を用いて大きな跳躍を行うには, ヘッド部とベース部 


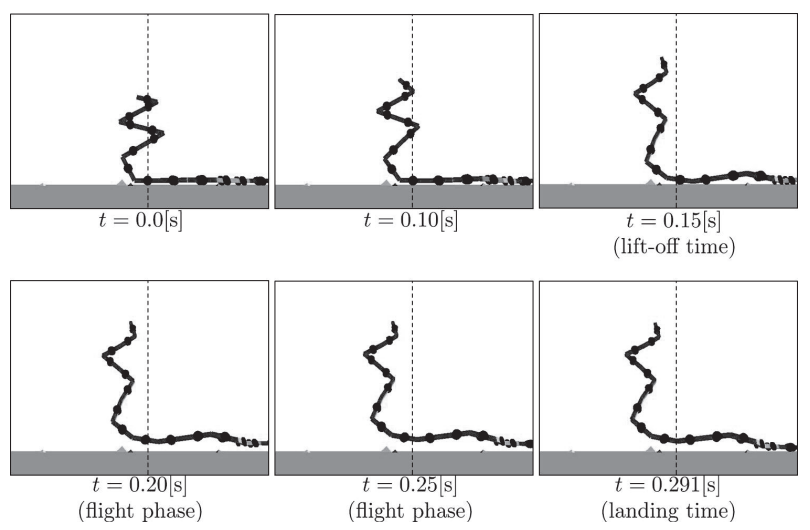

Fig. 13 The motion of the snake robot in ODE at $T_{b}=$ $1.17, \alpha_{b}=0.5$
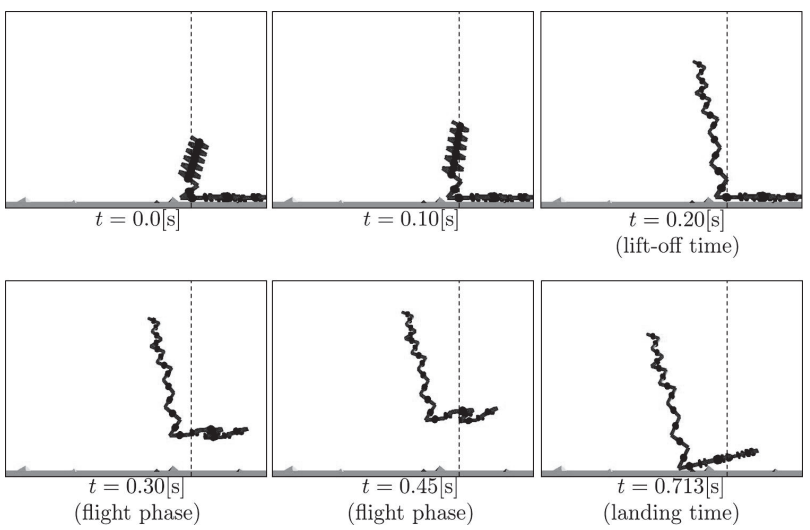

Fig. 14 The high jumping motion in ODE

の質量配分，ヘッド部初期姿勢が重要である、ロボットはヘッ ド部の動きによって重心を移動させるので，ヘッド部の質量は 大きければ大きいほど良い。また，重心を移動できる距離は初 期姿勢によって制約される。例えば, ヘッド部が跳躍方向に伸 びた姿勢を初期姿勢とする場合, 跳躍動作中には重心位置をほ とんど移動させることができない，重心位置の移動可能距離を 大きくするためには，ヘッド部は縮こまった初期姿勢が良いと 考えられる. そこで, ヘッド部のリンク数を $n_{h}=12$ に変更し, ベース部を除く関節角の初期值を $\left[\boldsymbol{\theta}_{1}, \cdots, \boldsymbol{\theta}_{n h}\right]^{T}=[0,2.74,0$, $-2.74,0,2.74,0,-2.74,0,2.74,0,-2.74,0,2.74,0,-2.74$, $0,2.74,0,-2.74,0,1.96,0,-2.62]^{T}$, 重心加速度に関するパ ラメータを $t_{f}=0.20[\mathrm{~s}], b x=-5, b y=0, b z=20$ とした場 合のシミュレーション結果を Fig. 14 に示す。ヘッド部が大き く伸び上がっており，ロボット全体も大きく跳躍していることが 分かる. なお, ベース部先頭リンクの最高到達高さは $0.32[\mathrm{~m}]$, 前方への跳躍距離は $0.26[\mathrm{~m}]$ であった。 このように, ヘッド部 とベース部の質量配分およびヘッド部初期姿勢を変更すること で，より大きな跳躍が実現できることが確認できた。跳躍量を さらに増やしたい場合, ヘッド部リンク数を増やすことで対応 できると考えられる。

\section{6. 実 機 実 験}

本章では実機を用いた拘束力だ円の検証実験を行う．前章まで

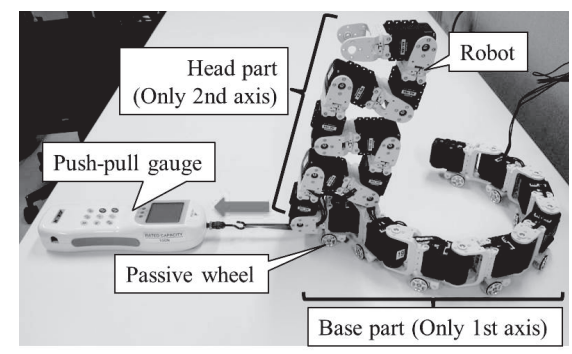

Fig. 15 The experimental system

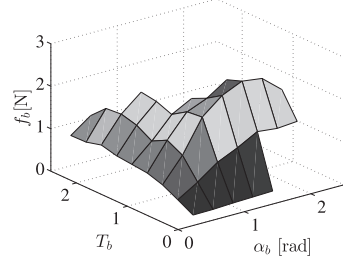

(a) Experiment

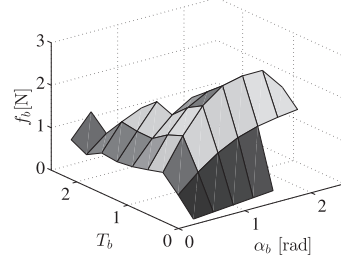

(b) Simulation
Fig. 16 The comparison of $f_{b}$

はロボットの関節として 2 軸直交関節を用いているが, 実機では 十分な可動範囲を確保することが難しい. そこでモデルの簡略化 を行い, ベース部は第 1 回転軸まわりの関節のみ,ヘッド部は第 2 回転軸まわりの関節のみで構成した. 本章は拘束力楕円の検証 を目的としており，ロボットの初期姿勢を実現する，という点 においてこの簡略化は問題ないと言える。製作実機および計測 環境を Fig. 15 に示す. アクチュエータは Dynamixel AX-18A （ROBOTIS）を用い, リンク数 $n=16, n_{h}=n_{b}=8$ とし, $m=0.083[\mathrm{~kg}], \quad 2 l=0.071[\mathrm{~m}], \mu=0.23$ である.

ロボットが滑らずに耐えられる跳躍方向の最大の力 $f_{b}$ は, 動き 始める直前の摩擦力（最大静止摩擦力）である。 そこで, Fig. 15 においてベース部先頭リンクを非常に小さい速度で跳躍方向（矢 印の方向）に引っ張っていき，プッシュプルゲージ RX-10（アイ コーエンジニアリング）を用いて引張力の最大值を測定し，その 值を $f_{b}$ として評価を行った。この際, ロボットの各関節は位置 制御にて静止させ, ヘッド部の初期角度 $\left[\psi_{1}, \cdots, \psi_{n_{h}}\right]$ は $[1.8$, $1.8,-1.8,-1.8,1.8,1.8,-1.8,-1.8]$ とした. ベース部相対角 $\left[\phi_{n_{h}+1}, \cdots, \phi_{n-1}\right]$ は式 $(35)$ を用い, $\alpha_{b}$ を $0.1 \leq \alpha_{b} \leq 4[\mathrm{rad}]$ の範囲で $0.3[\mathrm{rad}]$ 刻みで, $T_{b}$ を $0.1 \leq T_{b} \leq 2.5$ の範囲で 0.3 刻みで離散的に変化させて与え, 各姿勢において測定を行った。 測定は各姿勢につき 3 回行い, 平均值を実験結果とした。測定 結果を Fig. 16 (a) に示す。また, 比較対象として実機のパラ メータを導入したシミュレーションにおける $f_{b}$ の算出結果を Fig. 16 (b) に示す. シミュレーションと実験を比較すると, 相 対誤差はおおむね $30 \%$, 絶対誤差は $0.3[\mathrm{~N}]$ 程度に収まってい た. Fig. 16 より, 值の大きさと分布傾向の両面において実験結 果とシミュレーション結果がよく一致していることが分かる. 式 $(32)$ より $f_{b}$ と評価指標 $\sigma_{l}$ は比例関係にあることから, 本 論文にて提案した拘束力だ円に基づく評価指標 $\sigma_{l}$ は実際の物 理現象をうまく表現できており, 跳躍方向に滑りにくい初期姿 勢を選択する上で有効であることが確認された。しかしながら， $\left(\alpha_{b}, T_{b}\right)=(0.3,0.1)$ において相対誤差が最悪值 $290 \%$ となり， 
$\left(\alpha_{b}, T_{b}\right)=(0.3,2.2)$ に扔いて絶対誤差が最悪値 $0.61[\mathrm{~N}]$ となっ た．どちらも実験值の方が大きな值となっている，誤差原因と しては, 例えば関節角度分解能に起因するロボット姿勢の誤差, 車輪ごとの摩擦係数のばらつきなどが考えられる，特に誤差が 大きく出た前記の 2 条件では，モデルではゼロとしていた車輪 の転がり方向の摩擦が影響し, 理論值よりも大きな值が測定さ れたと推測される。

\section{7.おわりに}

本論文では，関節が能動ユニバーサルジョイントで構成され 三次元運動が可能な車輪拘束へビ型ロボットを対象に, 跳躍運 動中に滑りが生じないことを保証する制御則を設計と，効果的 な跳躍を実現するための初期姿勢決定のための評価指標の提案 を行った。ロボットは車輪により平らな床面と接触し, 車輪は横 滑りしないと仮定した上で動力学モデルを導出し，ロボットと 環境との間に働く床反力と摩擦力を考慮することで接地部分が 横滑りせずに跳躍運動を行う制御則を設計した，次に，跳躍運 動の目標值設計として, 横滑りしないための目標值の必要条件 を導出するとともに, ロボットの運動学的圥長性を利用し特異 点回避に貢献する形状可制御点の目標軌道を設計した。さらに 効果的な跳躍を行うための評価指標として拘束力だ円とべース 部重心角度を提案し, 接地部初期姿勢の最適化を行った。そし て数值シミュレーションおよび Open Dynamics Engine を用 いたシミュレーションにより提案制御則の有効性を確認し, 実 機実験により拘束力だ円に基づく評価指標の有効性を確認した。 アクチュエータ出力の問題はあるものの, 本研究によってへビ 型ロボットの新たな運動能力である跳躍実現のための一つの指 針を示すことができたと考えている，今後の課題としては，実 機による跳躍運動の実現，うねり推進を行いながらの跳躍，口
ボットの浮遊期における運動制御，着地制御などが挙げられる。

謝 辞 この研究は文部科学省科学研究費 (基盤研究 (B) 課 題番号 23360105）を使用して行われました。

\section{参 考 文 献}

[1] 広瀬茂男：生物機械工学. 工業調查会, 1987 .

[2] P. Prautsch and T. Mita: "Analysis and Control of a Gait of Snake Robot," Proc. International Conference on Control Applications, pp.496-507, 1999.

[ 3 ] S. Toyoshima, M. Tanaka and F. Matsuno: "A Study on Sinuslifting Motion of a Snake Robot With Sequential Optimization of a Hybrid System," IEEE Trans. on Automation Science and Engineering, pp.1-6, 2013.

[4] K. Lipkin, I. Brown, A. Peck, H. Choset, J. Rembisz, P. Gianfortoni and A. Naaktgeboren: "Differentiable and Piecewise Differentiable Gaits for Snake Robots," Proc. IEEE/RSJ Int. Conf. on Intelligent Robots and Systems, pp.1864-1869, 2007.

[ 5 ] T. Ikeda, Y. Iwatani, K. Suse and T. Mita: "Analysis and Design of Running Robots in Touchdown Phase," IEEE Conf. on Control Application, pp.496-501, 1999.

[6] T. Sugihara and Y. Nakamura: "Contact Phase Invariant Control for Humanoid Robot based on Variable Impedant Inverted Pendulum Model," IEEE International Conference on Robotics and Automation, pp.51-56, 2003.

[ 7 ] 松井猛, 加藤浩介, 坂和正敏, 宇野剛史, 東森充, 金子真： “生物群最 適化に基づくシリアルリンクロボットの跳躍高最大化”，日本ロボッ 卜学会誌, vol.26, no.1, pp.41-48, 2008 .

[ 8 ] Open Dynamics Engine, http://www.ode.org/

[9] 松野文俊, 茂木一貴：“穴長蛇型ロボットの運動学モデルに基づい た制御とユニット設計”, 計測自動制御学会論文集, vol.36, no.12, pp.1108-1116, 2000.

[10] 佐藤博毅, 田中基康, 松野文俊: “動力学モデルに基づく蛇型ロボットの 軌道追従制御”, 計測自動制御学会論文集, vol.42, no.6, pp.651-658, 2006.

[11] K. Hoshino, M. Tanaka and F. Matsuno: "Optimal Shape of a Snake Robot for Jumping," Proc. IEEE Int. Conf. on Robotics and Automation, pp.697-702, 2010.

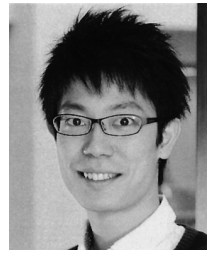

田中基康（Motoyasu Tanaka）

2009 年電気通信大学大学院電気通信学研究科博士 後期課程修了．同年キヤノン株式会社に勤務. 2012 年から電気通信大学大学院情報理工学研究科助教と なり, 現在に至る。 2007 年から 2009 年まで日本 学術振興会特別研究員 (DC1). 主にへビ型ロボッ 卜の研究に従事. 2004 年度日本機械学会畠山賞, 2006 年度同学会三浦賞, 2006 年度 IEEE Robotics and Automation Society Japan Chapter Young Award 受賞. 計測自動制御学 会, IEEE の会員. 博士 (工学).

（日本ロボット学会正会員）

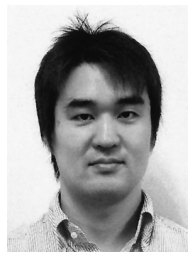

福島宏明 (Hiroaki Fukushima)

2001 年京都大学大学院情報学研究科博士課程修了 1999 年から 2004 年まで日本学術振興会特別研究 員，2004 年より電気通信大学助手，2009 年より 京都大学大学院工学研究科 (機械理工学専攻) 助 教, 2010 年より同講師となり, 現在に至る。主に, システム同定，ロバスト制御の研究に従事。計測 自動制御学会, システム制御情報学会, IEEE の会員. 博士（情報 学).

(日本ロボット学会正会員)

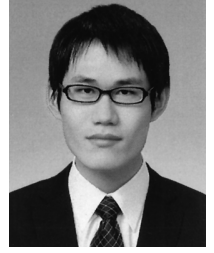

星野恵一（Keiichi Hoshino）

2009 年電気通信大学電気通信学部卒業. 2011 年電 気通信大学大学院電気通信学研究科博士前期課程修 了. 現在株式会社リコーに勤務.

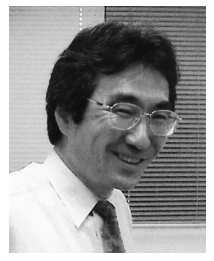

松野文俊（Fumitoshi Matsuno）

1986 年大阪大学大学院基礎工学研究科博士課程修 了. 大阪大学, 神戸大学, 東京工業大学, 電気通 信大学を経て, 2009 年京都大学大学院工学研究科 （機械理工学専攻）教授となり, 現在に至る。主に, ロボティクス・制御理論・レスキュー学に関する研 究に従事. 1993 年度システム制御情報学会論文賞, 2001 年度, 2006 年度計測自動制御学会論文賞, 2001 年度同学会武 田賞, 2006 年度船井情報科学振興賞, 2009 年度日本機械学会ロボッ ト・メカトロニクス部門学術業績賞, 2013 年度情報処理学会論文賞な どを受賞、日本機械学会 (フェロー), 計測自動制御学会 (フェロー), IEEE 等の会員. 工学博士.

（日本ロボット学会正会員） 